Article

\title{
A Case Study on Metal Contamination in Water and Sediment near a Coal Thermal Power Plant on the Eastern Coast of Bangladesh
}

\author{
Md. Solaiman Hossain ${ }^{1,2, *} \mathbb{\infty}$, Md. Kawser Ahmed ${ }^{2}$, Eurida Liyana ${ }^{1} \mathbb{D}$, Md. Shahadat Hossain ${ }^{1} \mathbb{B}$, \\ Yeasmin Nahar Jolly ${ }^{3}$ (D) M. Jamiul Kabir ${ }^{3}$, Shirin Akter ${ }^{3}$ and M. Safiur Rahman ${ }^{3,4}{ }^{(D)}$ \\ 1 Department of Oceanography, Shahjalal University of Science and Technology, Sylhet 3114, Bangladesh; \\ eurida06@student.sust.edu (E.L.); shahadat23@student.sust.edu (M.S.H.) \\ 2 Department of Oceanography, University of Dhaka, Dhaka 1000, Bangladesh; kawser_du@yahoo.com \\ 3 Atmospheric and Environmental Chemistry Laboratory, Atomic Energy Center Dhaka, \\ Dhaka 1000, Bangladesh; jolly_tipu@yahoo.com (Y.N.J.); jamiulkabir@gmail.com (M.J.K.); \\ shirinakhter43@yahoo.com (S.A.); safiur_baec@yahoo.com (M.S.R.) \\ 4 Water Quality Research Laboratory, Chemistry Division, Atomic Energy Centre, Bangladesh Atomic Energy \\ Commission, Dhaka 1000, Bangladesh \\ * Correspondence: solaiman-ocg@sust.edu
}

\section{check for}

updates

Citation: Hossain, M.S.; Ahmed M.K.; Liyana, E.; Hossain, M.S.; Jolly, Y.N.; Kabir, M.J.; Akter, S.; Rahman, M.S. A Case Study on Metal Contamination in Water and Sediment near a Coal Thermal Power Plant on the Eastern Coast of Bangladesh. Environments 2021, 8, 108. https://doi.org/10.3390/

environments 8100108

Academic Editor: Yu-Pin Lin

Received: 20 August 2021

Accepted: 10 October 2021

Published: 15 October 2021

Publisher's Note: MDPI stays neutral with regard to jurisdictional claims in published maps and institutional affiliations.

Copyright: (c) 2021 by the authors. Licensee MDPI, Basel, Switzerland. This article is an open access article distributed under the terms and conditions of the Creative Commons Attribution (CC BY) license (https:// creativecommons.org/licenses/by/ $4.0 /)$.

\begin{abstract}
This study has evaluated the potential ecological risk and human health risk for the contamination of nine elements $(\mathrm{Cu}, \mathrm{Cr}, \mathrm{Mn}, \mathrm{Zn}, \mathrm{As}, \mathrm{Pb}, \mathrm{Co}, \mathrm{Fe}$, and $\mathrm{Sr})$ in water and sediment samples in two seasons, i.e., before and after rainy season, by calculating several pollution indices such as pollution load index (PLI), potential ecological risk (PER), and target hazard quotient (THQ). Samples were analyzed for elemental concentration using energy dispersive $X$-ray fluorescence (EDXRF) spectrometry. This study found that waters in the Kutubdia channel are safe and standard for aquatic organisms. In addition, the study area's elemental concentration in water and sediments is still safe but moderately enriched with $\mathrm{Zn}$ and $\mathrm{Cu}$. The elemental concentration in water was observed to be high in the pre-monsoon season and vice versa in the sediment study. The result also reveals no potential ecological risk $(\mathrm{PER}<4)$ in the study site. However, the health risk index showed a noncarcinogenic risk (THQ $>1)$ for children and adults regarding the inhalation process where manganese was dominant. Apart from this, the pollution source was also identified by multivariate statistical analysis, including cluster analysis (CA) and principal component analysis (PCA) —and a natural pollution source prevalent was found.
\end{abstract}

Keywords: subtropical; ecosystem health; water parameters; contamination factor; Hazard Index

\section{Introduction}

Heavy metal emission results from increased industrialization and economic development in many regions and has adverse environmental impacts [1]. Heavy metals are a primary environmental concern as they are non-biodegradable, toxic, and have accumulation behaviors [2-4]. Further, heavy metal contamination poses a severe threat to the aquatic environment [5]. For this reason, many environmental researchers have paid their attention to elemental contamination in soil and water for the past few decades [6-9].

Among all types of elements (e.g., metal, metalloid, semi-metal, etc.), heavy metals are of serious concern as they have antagonistic effects on the ecosystem and human health. For instance, heavy metals can accumulate in living organisms and food chains, reducing species diversity and abundance, eventually leading to the degradation of the marine ecosystem [10]. Moreover, elements such as manganese (Mn), arsenic (As), chromium $(\mathrm{Cr})$, zinc $(\mathrm{Zn})$, copper $(\mathrm{Cu})$, and phosphorus $(\mathrm{P})$ are continuously entering the aquatic system from both anthropogenic and natural sources. They cause severe threats to the ecosystem and human health because of their long persistence, toxicity, accumulation, 
and biological magnifications-the concentration of metals increases in an organism and beyond the tolerable limit in the food chain [11]. To avoid degradation of the marine ecosystem and reduce human health risk by developing pollution control strategies, the current contamination of heavy metals and its associated potential threat to the ecosystem and human health needs to be assessed.

Metal ions level have been increased in water systems such as oceans, seas, estuaries, and rivers by both natural (for example, volcanisms, upwelling, ocean circulation, bioturbation, etc.) and anthropogenic activities (for instance, industrial wastes, dumping waste, sewage, etc.). Gas and offshore oil exploration, industrial and households waste, farming land waste, coal combustion, etc., have led to a rise in the metal load [12]. Metals are stored in three reservoirs in the aquatic system: sediment, water, and biota. Among these reservoirs, sediments have a higher storage capacity. Over $99 \%$ of the pollutants are stored in sediments, whereas far less than $1 \%$ remains to dissolve in water throughout the hydrological cycle [13]. Therefore, sediments are thought to be the primary sinks for heavy metals released into the aquatic environment $[14,15]$. Therefore, heavy metals in water and sediment analysis can provide a clear understanding of heavy metals contamination. Previously, contamination from the same elements in marine fishes was assessed in the same study area under the same research project [11]. In another study, the determination of seasonal variation of trace and heavy metals in sub-surface water and bottom-surface sediment were performed in the northern Bay of Bengal [12]. Currently, this study aims to assess the ecological risk and human health risk induced by nine (9) elements and the water quality parameters in the south-eastern coastal region of Bangladesh. Henceforward, this study will add a deeper understanding of the ecological and human health risk induced by several pollution indices in the south-eastern coastal zone of Bangladesh.

As a developing country, rapid industrial development is taking place in Bangladesh, and for this, human-induced activities are also significantly growing [16]. A significant number of point sources of pollution in this study area are the following-dry fish industry, salt production, bamboo industry, fisheries activities, etc. The Matarbari Coal-fired Power Plant is now in the under-construction phase, and will generate 1200 megawatts of electricity by coal combustion every day, which is very close to the study area [17]. The thermal power plant will be commissioned in 2024 [17]. It is supposed that the concentration of toxic trace elements might be increased in the Kutubdia Channel shortly after the commission of the power plant. Therefore, the assessment of ecological and human health risks induced by heavy metals is essential. Moreover, assessment from this study could be used as future reference data. The primary objectives of the study are:

(a) To assess the water quality parameters of the study area.

(b) To investigate the elemental concentration in sub-surface water and bottom-surface sediment

(c) To understand the sediment pollution level

(d) To identify the possible environmental and human health risks

(e) To identify the sources of the pollutants

\section{Materials and Methods}

\subsection{Study Area}

The study was conducted in the Kutubdia Channel near Matarbari, Moheshkhal, Cox's Bazar, Bangladesh. The sampling points were 4 to 8 kilometres from the Matarbari coal thermal power plant (under construction). The six sampling points (shown in Figure 1), comprised of the river, coast, and offshore areas, were selected in this location because intense human activities were evident-which poses threats of trace and heavy metal contamination in the drinking water and surrounding aquatic ecosystem. 


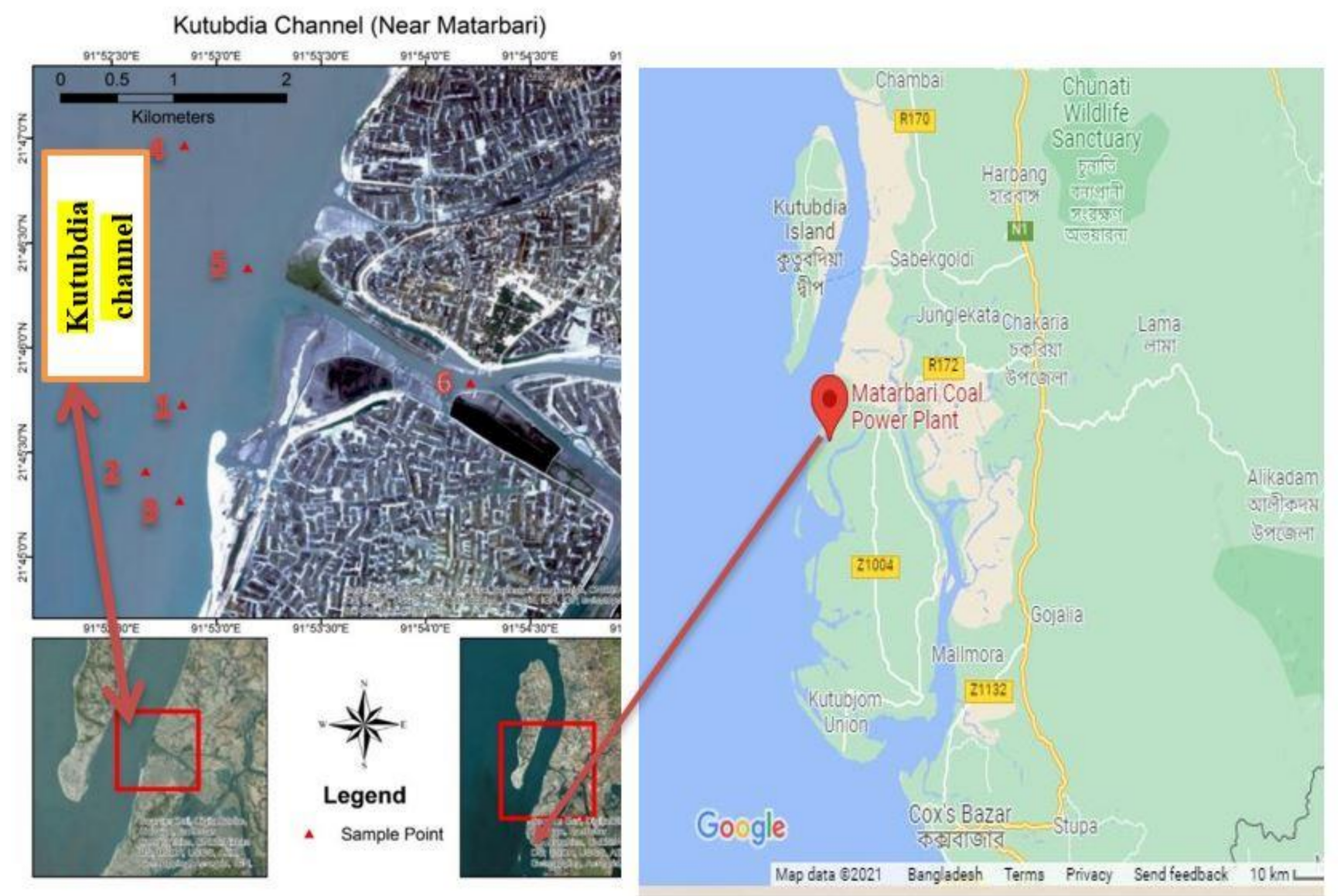

Figure 1. Sampling stations located in the Kutubdia Channel (near Matarbari), along the south-eastern Bay of Bengal.

\subsection{Water Multi-Parameters Detection}

Water temperature, $\mathrm{pH}, \mathrm{DO}$ (dissolved oxygen), EC (electrical conductivity), TDS (total dissolved solids), and salinity were determined in-situ by portable water multi-parameter detection meter (HANNA Instrument, HI98194, Germany). The probe was immersed into the water surface and waited for $5 \mathrm{~min}$ to stabilize the data on the multimeter screen. After $5 \mathrm{~min}$, the data were recorded, and the procedure was repeated for every sampling point.

\subsection{Sample Collection}

Sampling was carried out in 2015, spanning two periods-before the rainy season (January to May) and after the rainy season (September to December). Sediment samples were retrieved from the bottom seabed surface $(0-5 \mathrm{~cm})$ with the help of an Ekman grab sampler. Plastic $500 \mathrm{~mL}$ bottles were used for sampling sub-surface water from a depth of 0.5-1 cm from the water surface to avoid interference of surfactants. After taking sampled water to the laboratory, they were acidified using concentrated nitric acid ( $4 \mathrm{~mL} / \mathrm{L}$ sample) to prevent metal ions from adsorbing to the inside of the plastic bottles. The water samples were then capped and stored in a refrigerator until heavy metal analysis.

\subsection{Sample Preparation and Analysis}

Elemental concentrations in water and sediment samples were determined using EDXRF spectrometry (Epsilon 5, PANalytical, Australia). EDXRF is a well-established method for elemental concentration detection without destroying the samples [18]. It is a modern technique that is used enormously in the present day. Many researchers have used this technique to determine trace elements in their research [18-22]. We kept the sample under the table lamp for removing the moisture in terms of sediment sample analysis. 
Later on, sediment could be dried until constant weight using an oven set to 60 degrees Celsius. Ten tons of hydraulic pressure was used to make a pellet. Then, the pellet was kept on an EDXRF machine and the peak area was recorded. Finally, we determined the elemental concentration by ADMCA and FP-CROSS program using spectrum analysis of the peak area. The detailed methodology can be found elsewhere [19,22]. In terms of a water sample, a water sample was kept in a water bath where we mixed cellulose and stirred continually until the complete water evaporated. Then, the evaporated cellulose was kept in an oven until constant weight was achieved. After that, we prepared a pellet using two tons of hydraulic pressure. The rest of the procedures were the same as the sediment sample analysis [20].

\subsection{Sediment Pollution Assessment}

\subsubsection{Contamination Factor (CF) and Degree of Contamination (CD)}

For the determination of contamination status, the contamination factor $(\mathrm{CF})$ and the degree of contamination (CD) are used. The contamination level is calculated according to the following equations (Equations (1) and (2)), which were proposed by Hakanson [23].

$$
\begin{gathered}
C_{f}^{i}=\frac{\text { Measured concentration }}{\text { Background concentration }} \\
C_{d}=\sum_{i=1}^{n} \quad C_{f}^{i}
\end{gathered}
$$

where the background value of the metal $=$ average world surface shale values. The average background concentration of metals $(\mathrm{mg} / \mathrm{kg}$ ) in shale is $90,850,45,95,13,20,19,47200$, and 300 for chromium $(\mathrm{Cr})$, manganese $(\mathrm{Mn})$, copper $(\mathrm{Cu})$, zinc $(\mathrm{Zn})$, arsenic $(\mathrm{As})$, lead $(\mathrm{Pb})$, cobalt $(\mathrm{Co})$, iron $(\mathrm{Fe})$, and strontium $(\mathrm{Sr})$, respectively [24]. The contamination factors were classified into four groups: $\mathrm{C}_{\mathrm{f}}^{\mathrm{i}}<1$ indicates low contamination; $1 \leq \mathrm{C}_{\mathrm{f}}^{\mathrm{i}}<3$ indicates moderate contamination; $3 \leq \mathrm{C}_{\mathrm{f}}^{\mathrm{i}}<6$ indicates considerable contamination; and $6 \leq \mathrm{C}_{\mathrm{f}}^{\mathrm{i}}$ indicates very high contamination. In terms of $C_{d}$, it is classified as $C_{d}<8$ indicates a low degree of contamination; $8 \leq \mathrm{C}_{\mathrm{d}}<16$ indicates a moderate degree of contamination; $16 \leq \mathrm{C}_{\mathrm{d}}<32$ indicates a considerable degree of contamination; and $32 \leq \mathrm{C}_{\mathrm{d}}$ suggests a very high degree of contamination [23].

\subsubsection{Modified Degree of Contamination (MCD)}

MCD can be expressed in Equation (3), which Abrahim and Parker coined [25].

$$
\mathrm{mC}_{\mathrm{d}}=\frac{\sum_{\mathrm{i}=1}^{\mathrm{n}} \mathrm{C}_{\mathrm{f}}^{\mathrm{i}}}{\mathrm{n}}
$$

It is categorized by ${ }^{\mathrm{m}} \mathrm{C}_{\mathrm{d}}<1.5,1.5 \leq{ }^{\mathrm{m}} \mathrm{C}_{\mathrm{d}}<2,2 \leq{ }^{\mathrm{m}} \mathrm{C}_{\mathrm{d}}<4,4 \leq{ }^{\mathrm{m}} \mathrm{C}_{\mathrm{d}}<8,8 \leq{ }^{\mathrm{m}} \mathrm{C}_{\mathrm{d}}<16$, $16 \leq{ }^{\mathrm{m}} \mathrm{C}_{\mathrm{d}}<32$, and ${ }^{\mathrm{m}} \mathrm{C}_{\mathrm{d}} \geq 32$, which indicate nil to very low, low, moderate, high, very high, extremely high, and ultra-high degree of contamination, respectively [25].

\subsubsection{The Pollution Load Index (PLI)}

According to Tomlinson [26], PLI is the nth root of the metals' concentrations' multiplications. He classified the pollution level based on PLI values $\leq 0,0$ to $\leq 1, \geq 1$ indicates perfection, baseline, and progressive deterioration. It is calculated by the following equation (Equation (4)).

$$
\mathrm{PLI}=(\mathrm{CF} 1 \times \mathrm{CF} 2 \times \mathrm{CF} 3 \times \mathrm{CFn}) 1 / \mathrm{n}
$$

where $\mathrm{CF}$ is the contamination factor.

\subsubsection{Geoaccumulation Index ( $\left.\mathrm{I}_{\text {geo }}\right)$}

The Geoaccumulation Index $\left(\mathrm{I}_{\text {geo }}\right)$ was calculated to determine the ecosystem's metals contamination rate or level. This expression was proposed by Müller [27] to calculate 
metals concentration in studied sediments by comparing with undisturbed or crustal sediment (control) levels. It is classified into seven classes in relation to contamination levels: Unpolluted (Class 0 , $\mathrm{I}_{\text {geo }} \leq 0$ ), unpolluted to moderately polluted (Class $1,0<\mathrm{I}_{\text {geo }}<1$ ), moderately polluted (Class $2,1<\mathrm{I}_{\text {geo }}<2$ ), moderately to strongly polluted (Class 3 , $2<\mathrm{I}_{\text {geo }}<3$ ), strongly polluted (Class $4,3<\mathrm{I}_{\text {geo }}<4$ ), strongly to extremely polluted (Class $\left.5,4<\mathrm{I}_{\text {geo }}<5\right)$, and extremely polluted (Class 6 , $\mathrm{I}_{\text {geo }}>5$ ).

The following pattern, Equation (5), expresses the geo-accumulation index (Igeo).

$$
\mathrm{I}_{\text {geo }}=\log _{2}\left(\frac{\mathrm{C}_{\mathrm{n}}}{1.5 \mathrm{~B}_{\mathrm{n}}}\right)
$$

where $C_{n}$ is the measured concentration of the sediment for metal (n), $B_{n}$ is the geochemical background value of metal (n), and factor 1.5 is the possible variations of background data due to lithogenic impacts [28].

\subsubsection{Enrichment Factors (EF)}

In the present study, we used iron (Fe) to compute EF because it is the fourth central element in the Earth's crust and often has no contamination concern. Additionally, Fe is the best-normalized metal due to its noble characteristics. Further, Fe's geochemistry is almost the same with all trace metals, uniformly distributed in the sediment, etc. [29,30]. Most researchers used Fe successfully to normalize metals contamination in river and coastal sediments [31,32]. The EF for Fe-normalized data is defined by Equation (6) [33].

$$
\text { Enrichment Factor }(\mathrm{EF})=\frac{\left\lceil\mathrm{M}_{\mathrm{x}} / \mathrm{Fe}_{\mathrm{x}}\right\rceil_{\text {sample }}}{\left[\mathrm{M}_{\mathrm{ref}} / \mathrm{Fe}_{\mathrm{ref}}\right]_{\text {Background }}}
$$

$\mathrm{M}_{\mathrm{X}}$ is the concentration of metal in the studied sample. $\mathrm{F}_{\mathrm{ex}}$ is the concentration of $\mathrm{Fe}$ in the studied sample. $\mathrm{M}_{\text {ref }}$ is the concentration of metals in the average shale, and $\mathrm{Fe}_{\text {ref }}$ is the average shale of Fe. The classification of EF: $\mathrm{EF}<1$ indicates no enrichment, $\mathrm{EF}<3$ is minor enrichment, $\mathrm{EF}=3-5$ is moderate enrichment, $\mathrm{EF}=5-10$ is moderately severe enrichment, $\mathrm{EF}=10-25$ is severe enrichment, $\mathrm{EF}=25-50$ is very severe enrichment, and $\mathrm{EF}>50$ is extremely severe enrichment $[29,30]$

\subsection{Potential Ecological Risk (PER) Assessment}

PER is determined for knowing the risk level of the ecological habitat of an ecosystem. It is also assessed using metal concentration data of sediment samples. The risk index value indicates the pollution status calculated by solving the following three equations (Equations (7)-(9)).

$$
\begin{gathered}
\mathrm{E}_{\mathrm{r}}^{\mathrm{i}}=\mathrm{T}_{\mathrm{r}}^{\mathrm{i}} \mathrm{C}_{\mathrm{f}}^{\mathrm{i}} \\
\mathrm{C}_{\mathrm{f}}^{\mathrm{i}}=\mathrm{C}_{\mathrm{o}}^{\mathrm{i}} / \mathrm{C}_{\mathrm{n}}^{\mathrm{i}} \\
\mathrm{R}_{\mathrm{I}}=\sum \mathrm{E}_{\mathrm{r}}^{\mathrm{i}}
\end{gathered}
$$

where, $\mathrm{E}_{\mathrm{r}}^{\mathrm{i}}$ is the monomial potential ecological risk factor, $\mathrm{C}_{\mathrm{o}}^{\mathrm{i}}$ is the heavy metal concentration and $\mathrm{T}_{\mathrm{r}}^{\mathrm{i}}$ is the toxic response factor for a given substance, which accounts for the toxic and sensitivity requirement. The $\mathrm{T}_{\mathrm{r}}^{\mathrm{i}}$ values are $2,1,5,1,10,5$, and 5 for $\mathrm{Cr}, \mathrm{Mn}, \mathrm{Cu}$, $\mathrm{Zn}, \mathrm{As}, \mathrm{Pb}$, and $\mathrm{Co}$, respectively [23]. However, $\mathrm{E}_{\mathrm{r}}^{\mathrm{i}}$ has five categories, i.e., $\mathrm{E}_{\mathrm{r}}^{\mathrm{i}}<40$ for low, $40 \leq \mathrm{E}_{\mathrm{r}}^{\mathrm{i}}<80$ for moderate, $80 \leq \mathrm{E}_{\mathrm{r}}^{\mathrm{i}}<160$ for considerable, $160 \leq \mathrm{E}_{\mathrm{r}}^{\mathrm{i}}<320$ for high, and $\mathrm{E}_{\mathrm{r}}^{\mathrm{i}} \geq 320$ for very high risk and four categories for $\mathrm{RI}$, i.e., $\mathrm{RI}<150$ for low, $150 \leq \mathrm{RI}<300$ for moderate, $300 \leq \mathrm{RI}<600$ for considerable, and $\mathrm{R}_{\mathrm{I}} \geq 320$ for very high risk. 


\subsection{Human Health Risk Assessment Index}

We performed a risk assessment measuring the index linked to the soil by calculating the Average Daily Dose (ADD, mg element $\mathrm{kg}^{-1}$ bodyweight day ${ }^{-1}$ ) for three groups of persons: children, adult males, and adult females, as described in Equation (10).

$$
\mathrm{ADD}=\mathrm{Cs} \times\left(\mathrm{IR} \times \mathrm{EF} \times \mathrm{ED} \times 10^{-6}\right) /(\mathrm{BW} \times \mathrm{AT})
$$

where $\mathrm{Cs}$ = concentration of metals in sediment, IR = Ingestion Rate of soil (children: 200; adults: $100 \mathrm{mg}$ dust day-1); $\mathrm{EF}$ = exposure frequency (children: 350; adults: 250 days year-1); $\mathrm{ED}=$ exposure duration (children: 6 years; adults: 25 years); BW = bodyweight (children: $15 \mathrm{~kg}$; adults males: $68 \mathrm{~kg}$; adult females: $58 \mathrm{~kg}$ ); AT = averaging time (children: six 365 day years $=2190$ days; adults: 9125 days); and $10^{-6}$ is for unit conversion; values were obtained as per $[9,34]$.

Then Hazard Quotient (unitless), HQ, was calculated by the following equation, Equation (11).

$$
\mathrm{HQ}=\mathrm{ADD} / \mathrm{RfD}
$$

where RfD is the PTE oral reference dose (units same as those of ADD) for ingestion: $\mathrm{Mn}=1.4 \times 10^{-1}, \mathrm{Fe}=7 \times 10^{-1}, \mathrm{Cu}=0.04, \mathrm{Zn}=0.3, \mathrm{Sr}=600$, and $\mathrm{Pb}=0.0035$; for inhalation: $\mathrm{Mn}=1.4 \times 10^{-5}, \mathrm{Cu}=0.0402, \mathrm{Zn}=0.3$, and $\mathrm{Pb}=0.00352$; for dermal: $\mathrm{Mn}=1.8 \times 10^{-3}$, $\mathrm{Cu}=0.012, \mathrm{Zn}=0.06$, and $\mathrm{Pb}=0.000525$ [9,35-37]. Then, we calculated the sum of HQ values of all PTEs, i.e., Hazard Index (HI). Values of HQ and $\mathrm{HI}$ of $>1$ indicate a high probability of human health risk.

\subsection{Statistical Analysis}

We performed a multivariate statistical analysis including correlation, cluster analysis, and principal component analysis. A multivariate statistical analysis is one of the best techniques to obtain a clear idea about the relationship between different kinds of data and whether it is significant or not. The details of this statistical analysis can be found elsewhere [38]. Moreover, the identification of the sources of the trace metal might be manageable by this multivariate statistical analysis, particularly by cluster analysis (CA) and principal component analysis (PCA) [39,40].

\subsection{Accuracy and Precision}

The quality accuracy (QA) and quality control (QC) were checked for all the studied elements for both samples using a certified reference material of marine sediment-IAEA 433, Austria. This is a popular method worldwide, and it was done based on a solid matrix. In addition, we could not measure any elements from the water sample directly. As a result, we added cellulose in the water sample for making a solid pellet allowing the determination of elemental concentration. The results for the recoveries were between 90 and $110 \%$, and the accuracy was within $10 \%$. Detailed information on the QA/QC is available elsewhere [12].

\section{Results and Discussion}

\subsection{Physicochemical Qualities of Water}

Physicochemical parameters are essential to assessing the quality and extent of water purity for drinking, domestic, agricultural, or industrial activities. Considering water's physicochemical parameters also helps us to understand the state or stressors of a natural ecosystem [41]. Various physicochemical parameters of water (temperature, DO, salinity, $\mathrm{pH}$, TDS, and EC) at the six sampling stations in Kutubdia Channel during pre-monsoon and post-monsoon seasons are shown in Table 1. 
Table 1. Physicochemical parameters of Kutubdia Channel water samples during pre-monsoon (Pre M) and post-monsoon (Post M).

\begin{tabular}{|c|c|c|c|c|c|c|c|c|c|c|c|c|c|c|}
\hline \multirow[t]{2}{*}{$\begin{array}{c}\text { Sampling } \\
\text { Station No. }\end{array}$} & \multirow[t]{2}{*}{ Latitude } & \multirow[t]{2}{*}{ Longitude } & \multicolumn{2}{|c|}{$\begin{array}{c}\text { Temp } \\
\left({ }^{\circ} \mathrm{C}\right)\end{array}$} & \multicolumn{2}{|c|}{$\begin{array}{c}\text { DO } \\
(\mathrm{ppm})\end{array}$} & \multicolumn{2}{|c|}{$\begin{array}{l}\text { Salinity } \\
\text { (PSU) }\end{array}$} & \multicolumn{2}{|c|}{$\mathrm{pH}$} & \multicolumn{2}{|c|}{$\begin{array}{c}\text { TD } \\
\text { S(g/L) }\end{array}$} & \multicolumn{2}{|c|}{$\begin{array}{c}\mathrm{EC} \\
(\mathrm{mS} / \mathrm{cm})\end{array}$} \\
\hline & & & $\begin{array}{c}\text { Pre } \\
\text { M }\end{array}$ & $\begin{array}{c}\text { Post } \\
\text { M }\end{array}$ & $\begin{array}{c}\text { Pre } \\
\text { M }\end{array}$ & $\begin{array}{c}\text { Post } \\
\text { M }\end{array}$ & $\begin{array}{c}\text { Pre } \\
\text { M }\end{array}$ & $\begin{array}{c}\text { Post } \\
\text { M }\end{array}$ & $\begin{array}{c}\text { Pre } \\
\text { M }\end{array}$ & $\begin{array}{c}\text { Post } \\
\text { M }\end{array}$ & $\begin{array}{c}\text { Pre } \\
\text { M }\end{array}$ & $\begin{array}{l}\text { Post } \\
\text { M }\end{array}$ & $\begin{array}{c}\text { Pre } \\
\text { M }\end{array}$ & $\begin{array}{c}\text { Post } \\
\text { M }\end{array}$ \\
\hline 01 & $21^{\circ} 45.269^{\prime} \mathrm{N}$ & $91^{\circ} 52.824^{\prime} \mathrm{E}$ & 28.1 & 29.7 & 7.51 & 7.11 & 31.0 & 22.10 & 8.35 & 7.89 & 29.7 & 21.30 & 52.8 & 37.8 \\
\hline 02 & $21^{\circ} 45.409^{\prime} \mathrm{N}$ & $91^{\circ} 52.661^{\prime} \mathrm{E}$ & 28.3 & 29.3 & 7.58 & 7.16 & 30.9 & 21.87 & 8.52 & 7.95 & 29.6 & 20.96 & 51.7 & 37.2 \\
\hline 03 & $21^{\circ} 45.728^{\prime} \mathrm{N}$ & $91^{\circ} 52.838^{\prime} \mathrm{E}$ & 29.0 & 29.8 & 7.89 & 7.20 & 30.9 & 21.94 & 8.52 & 8.06 & 29.8 & 21.11 & 52.7 & 37.3 \\
\hline 04 & $21^{\circ} 46.381^{\prime} \mathrm{N}$ & $91^{\circ} 53.149^{\prime} \mathrm{E}$ & 28.5 & 29.7 & 7.77 & 7.20 & 30.8 & 21.53 & 8.51 & 8.05 & 29.6 & 20.21 & 51.7 & 36.0 \\
\hline 05 & $21^{\circ} 46.966^{\prime} \mathrm{N}$ & $91^{\circ} 52.847^{\prime} \mathrm{E}$ & 28.1 & 29.8 & 7.87 & 6.99 & 30.5 & 21.95 & 8.37 & 8.02 & 29.4 & 20.77 & 51.0 & 36.9 \\
\hline 06 & $21^{\circ} 45.832^{\prime} \mathrm{N}$ & $91^{\circ} 54.213^{\prime} \mathrm{E}$ & 28.7 & 30.3 & 7.43 & 7.25 & 31.3 & 21.68 & 8.46 & 8.04 & 30.1 & 20.90 & 52.4 & 37.1 \\
\hline Average & & & 28.45 & 29.77 & 7.68 & 7.15 & 30.9 & 21.8 & 8.46 & 8 & 29.7 & 20.88 & 52.05 & 37.05 \\
\hline
\end{tabular}

Water temperatures were higher in all the six stations during post-monsoon (average $=29.77^{\circ} \mathrm{C}$ ) and lower during pre-monsoon season (average $=28.45^{\circ} \mathrm{C}$ ). Higher water (surface) temperature in post-monsoon could be due to the influx of freshwater in the coast via river runoff discharging excess water from the monsoon period; solar heating of freshwater is faster than saline water. In our study, the average levels of DO in the Kutubdia Channel were found as 7.68 ppm (during pre-monsoon) and 7.15 ppm (during post-monsoon), both of which were higher than the standard minimum requirement of DO levels for drinking, fishing, industrial, and irrigation purposes $(6,4.6,5$, and $5 \mathrm{ppm}$, respectively) set by the Department of Public Health and Engineering (DPHE), Bangladesh [42]. Water turbulence is very high in the study area. Apart from that, two freshwater sources have coincided with the northern Bay of Bengal. Thus, Kutubdia Channel is a dynamic estuarine region where airflow is also high. All these factors are owing to the high level of DO in the study site. However, numerous studies agree that DO concentrations above 6.5-8 ppm are considered healthy for the most aquatic lives [43]. From this investigation, the average water salinity recorded for pre-monsoon was 30.9 PSU $(\approx 30,900 \mathrm{mg} / \mathrm{L})$, and for post-monsoon, it was $21.8 \mathrm{PSU}(\approx 21,800 \mathrm{mg} / \mathrm{L})$ in Kutubdia Channel. According to Bangladesh guidelines, freshwater salinity $<1000 \mathrm{mg} / \mathrm{L}$ is considered safe for drinking water. Two other categories under this guideline include $1000-2000 \mathrm{mg} / \mathrm{L}$ (slightly saline) and $=2000 \mathrm{mg} / \mathrm{L}$ (moderately saline) water which are considered unsafe for drinking. These guidelines were proposed based on expertise and judgment by authors since other standards for salinity are not yet established [44]. Comparing these guidelines, we can conclude that the water of Kutubdia Channel is highly unsafe for drinking purposes as the water salinity levels in both seasons were much higher than the permissible safety limits. Water $\mathrm{pH}$ is an essential parameter for regulating homeostasis and metabolic processes inside the human body [45]. DPHE [42] set the permissible maximum limit $\mathrm{pH}$ in industrial water (6.0-9.5), fishing water (6.5-8.5), and drinking water (6.5-8.5) for Bangladesh. In pre-monsoon, the average water $\mathrm{pH}$ in Kutubdia Channel was 8.46, and in post-monsoon, it was 8 . Higher $\mathrm{pH}$ values during pre-monsoon could be due to water evaporation via the loss of dissolved half-bound carbon dioxide and precipitation of mono-carbonate in the water [46]. The average $\mathrm{pH}$ values in both seasons were in line with the DPHE [42] guidelines, showing that the water in the Kutubdia Channel is safe nearly all year round for drinking, fishing, and industrial activities in terms of its $\mathrm{pH}$. Contaminants in water more significant than 2 microns are termed total dissolved solids (TDS), and they comprise inorganic salts and a minute quantity of organic matter. Average TDS values of the Kutubdia Channel water were $29.7 \mathrm{~g} / \mathrm{L}$ in pre-monsoon and $20.21 \mathrm{~g} / \mathrm{L}$ in post-monsoon, which were much higher than the maximum acceptable level of $1000 \mathrm{mg} / \mathrm{L}(=1 \mathrm{~g} / \mathrm{L})$ set by [47] for drinking water. Electrical conductivity $(\mathrm{EC})$ is among the most commonly measured physical water parameters due to its numerous vital uses, including its role in acting as an early indicator of pollution or other changes in a water body [48]. The sample waters' average EC values ( $52.05 \mathrm{mS} / \mathrm{cm}$ during pre-monsoon; $37.05 \mathrm{mS} / \mathrm{cm}$ during post-monsoon) were also much 
higher than $1.5 \mathrm{mS} / \mathrm{cm}$ [47] guideline for drinking water. The Kutubdia Channel meets the Bay of Bengal on both ends, which is owed to the water's high salinity. Since TDS and EC are correlated to salinity, TDS and EC in the water were also increased. Most of the parameters were slightly elevated during pre-monsoon than a post-monsoon season (as presented in Figure 2).

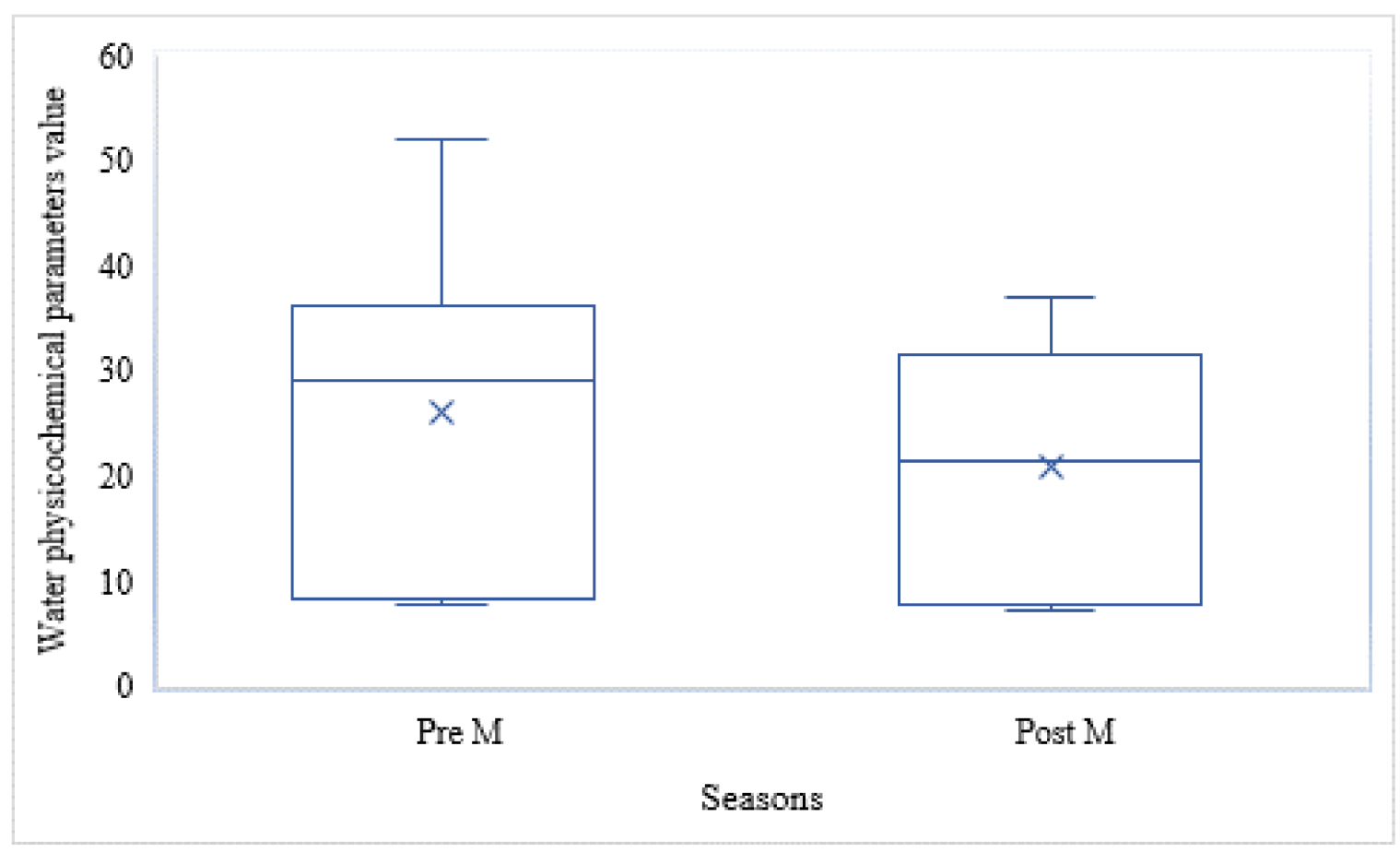

Figure 2. Seasonal variation of water quality parameters.

All the water quality parameters, except temperature, showed higher pre-monsoon values than the post-monsoon period. Higher TDS and salinity during pre-monsoon are results of high evaporation rates of water. Electrical conductivity (EC) depends on temperature, salinity, and TDS of water [49,50]. Higher EC during pre-monsoon is associated with high temperature and high evaporation rates of water. Subsequently, lower conductivity in the post-monsoon season is due to heavy monsoon rainfall and freshwater river discharges, diluting the electrolytes (ions) concentration in the water and reducing EC. TDS can also affect water $\mathrm{pH}$, and high TDS often indicates high alkalinity [51]. Hence higher water $\mathrm{pH}$ during pre-monsoon is a consequence of higher TDS in that season. On the contrary, the average water temperature was higher during the post-monsoon $\left(29.77^{\circ} \mathrm{C}\right)$ than the pre-monsoon season $\left(28.45^{\circ} \mathrm{C}\right)$. This data depicts the well-known bi-modal distribution of seasonal surface temperature in the Bay of Bengal, with a higher peak during the postmonsoon (October) period, which occurs due to the secondary warming phase coming soon after the withdrawal of monsoon over the Bay [52,53].

\subsection{Trace and Heavy Metal Contamination in Meghna Estuarine Water}

Variation of the mean concentration of different trace and heavy metals during premonsoon and post-monsoon in the surface water of Kutubdia Channel are summarized in Table 2, along with standard drinking water guidelines established by the World Health Organization (WHO). 
Table 2. Average concentration $(\mathrm{mg} / \mathrm{L})$ of metals in the water sample, $\mathrm{n}=12$.

\begin{tabular}{|c|c|c|c|c|c|}
\hline Elements & Pre-Monsoon & Post Monsoon & $\begin{array}{l}\text { WHO Standard [47] } \\
\quad(\mathrm{ppm}=\mathrm{mg} / \mathrm{L})\end{array}$ & $\begin{array}{c}\text { Bangladesh } \\
\text { Standard [42] } \\
(\mathrm{mg} / \mathrm{L})\end{array}$ & $\begin{array}{c}\text { U.S. EPA } \\
\text { Standard [34] } \\
(\mathrm{mg} / \mathrm{L})\end{array}$ \\
\hline $\mathrm{Cr}$ & $0.060 \pm 0.004$ & $0.060 \pm 0.003$ & 0.05 & 0.05 & 0.01 \\
\hline Mn & $0.084 \pm 0.009$ & $0.090 \pm 0.009$ & 0.5 & 0.1 & 0.05 \\
\hline $\mathrm{Cu}$ & $0.030 \pm 0.003$ & $0.026 \pm 0.004$ & 2 & 1 & 1.3 \\
\hline $\mathrm{Zn}$ & $0.087 \pm 0.016$ & $0.073 \pm 0.006$ & NG & 5 & 5 \\
\hline As & BDL & BDL & 0.01 & 0.05 & 0.01 \\
\hline $\mathrm{Pb}$ & $0.026 \pm 0.002$ & $0.026 \pm 0.003$ & 0.01 & 0.05 & 0.015 \\
\hline $\mathrm{Co}$ & BDL & BDL & $\mathrm{NG}$ & NG & $0.7^{*}$ \\
\hline $\mathrm{Fe}$ & $0.080 \pm 0.012$ & $0.055 \pm 0.003$ & 2 & $0.3-1.0$ & 0.3 \\
\hline $\mathrm{Sr}$ & $0.511 \pm 0.011$ & $0.413 \pm 0.012$ & NG & NG & 4 \\
\hline
\end{tabular}

$\mathrm{BDL}=$ below detection limit $(<0.02 \mathrm{mg} / \mathrm{L}) ; \mathrm{NG}=$ no guideline available. * U.S. EPA defined the EWG Health Guideline [54] of $70 \mathrm{ppb}$ $(=0.07 \mathrm{ppm})$ of cobalt in drinking water as a standard for testing under the Unregulated Contaminant Monitoring Rule program. However, EPA has not classified any regulatory guideline for cobalt in drinking water. U.S. EPA (U.S. Environmental Protection Agency), as well as Bangladesh Drinking Water Standard (BDWS) set by the Department of Public Health Engineering (DPHE) of Bangladesh.

We analyzed nine metals (i.e., $\mathrm{Cr}, \mathrm{Mn}, \mathrm{Cu}, \mathrm{Zn}, \mathrm{As}, \mathrm{Pb}, \mathrm{Co}, \mathrm{Fe}$, and $\mathrm{Sr}$ ) for water and sediment samples. All metals were nearly evenly distributed in the surface waters of the study area. Among all the metals, strontium (Sr) concentrations were the highest (i.e., mean $0.511 \mathrm{mg} / \mathrm{L}$ in pre-monsoon and $0.413 \mathrm{mg} / \mathrm{L}$ in post-monsoon). USEPA has established the maximum permissible level of Sr in drinking water of $4 \mathrm{mg} / \mathrm{L}$, which far exceeds the level of $\mathrm{Sr}$ found in the present study [55]. Arsenic ( $\mathrm{As}$ ) and lead $(\mathrm{Pb})$ are two of the most toxic naturally occurring elements. Bangladesh is one of the worst affected countries globally with drinking water contamination of arsenic from geological origin [56]. Arsenic and lead are classified as human carcinogens, and chronic exposure to these causes' cancer and noncarcinogenic disorders such as kidney disease, impaired cognitive function, and other toxicological effects [3,47]. However, in the present observation, arsenic (As) and cobalt (Co) were absent in water samples, or their concentrations were below the detection limit $(<0.02 \mathrm{mg} / \mathrm{L})$. The mean concentration of $\mathrm{Pb}$ was found to be the same during both of the seasons (mean $=0.026 \mathrm{mg} / \mathrm{L}$ ), which was much lower than the recommended values $(0.01,0.05$, and $0.015 \mathrm{mg} / \mathrm{L})$ set by WHO [47], DPHE [42], and USEPA [34], respectively. Ingestion of chromium $(\mathrm{Cr})$ through drinking water is a cause of increased human lung and stomach cancers [57]. Mean levels of $\mathrm{Cr}$ in surface water were also found to be the same during both pre- and post-monsoon, and the observed concentration (mean $=0.060 \mathrm{mg} / \mathrm{L}$ ) was also much lower than the recommended values of $0.05 \mathrm{mg} / \mathrm{L}$ set by WHO [47] and DPHE [42], and $0.01 \mathrm{mg} / \mathrm{L}$ set by USEPA [34].

Copper $(\mathrm{Cu})$ concentration in pre-monsoon (mean $0.030 \mathrm{mg} / \mathrm{L}$ ) was slightly elevated than in the post-monsoon period (mean $0.026 \mathrm{mg} / \mathrm{L}$ ). Moreover, $\mathrm{Cu}, \mathrm{Zn}, \mathrm{Fe}$, and $\mathrm{Sr}$ levels were also found slightly higher during the pre-monsoon than those in the post-monsoon period. Such differences arose due to the dilution of the surface water because of the deluge of precipitation and river influx after the monsoon. The mean $\mathrm{Cu}$ and Fe concentrations in both seasons were found well below the WHO, DPHE, and U.S. EPA guideline values for drinking water. Zn concentrations in Kutubdia Channel water (mean $0.087 \mathrm{mg} / \mathrm{L}$ in pre-monsoon, $0.073 \mathrm{mg} / \mathrm{L}$ in post-monsoon) were well below the maximum permitted concentration of $\mathrm{Zn}$ in drinking water of $5 \mathrm{mg} / \mathrm{L}$, set by DPHE [42]. Zn is an essential nutrition mineral and serves many physiological functions in the human body, with food constitutes its most important source. Thus, drinking water is not regarded as a potential source of this nutritional element [58]. Manganese (Mn) is a well-known mutagen [59]. It was the only metal whose concentration was found higher during post-monsoon (mean $0.090 \mathrm{mg} / \mathrm{L}$ ) than in pre-monsoon (mean $0.084 \mathrm{mg} / \mathrm{L}$ ); it is negligible where the variation is insignificant $(p>0.05)$. However, both values were below the maximum permissible values of 0.5, 0.1, $0.05 \mathrm{mg} / \mathrm{L}$ recommended by DPHE [42] and WHO [34], respectively. Overall, in the regard that the level of all the aforementioned heavy metals was well below the standard safe level for drinking water, we can conclude that the surface water of Kutubdia 
Channel is safe for drinking by humans. However, the trace metal concentration data variation between two seasons, i.e., pre-monsoon and post-monsoon, is not significant $(p>0.05)$.

\subsection{Elemental Concentration in Sediment}

The elemental concentration and seasonal variation of different heavy metals found in the sediments of the Kutubdia channel are represented in Table 3.

Table 3. Average concentration $(\mathrm{mg} / \mathrm{Kg})$ of metals in the sediment sample, $\mathrm{n}=12$.

\begin{tabular}{ccccccc}
\hline & & & & \multicolumn{2}{c}{$\begin{array}{c}\text { Sediment Quality } \\
\text { Guidelines [60] }\end{array}$} \\
\hline Metals & Pre-Monsoon & Post-Monsoon & $\begin{array}{c}\text { World Average } \\
\text { Shale [24] }\end{array}$ & TEL & PEL & SEL \\
\hline $\mathrm{Cr}$ & $10.69 \pm 1.46$ & $12.22 \pm 0.82$ & 90 & 37.3 & 90 & 110 \\
$\mathrm{Mn}$ & $570.67 \pm 31.64$ & $606.25 \pm 43.83$ & 850 & $\mathrm{NA}$ & $\mathrm{NA}$ & 1100 \\
$\mathrm{Cu}$ & $145.61 \pm 21.87$ & $135.41 \pm 9.38$ & 45 & 35.7 & 197 & 110 \\
$\mathrm{Zn}$ & $149.83 \pm 12.59$ & $146.92 \pm 6.43$ & 95 & 123 & 315 & 820 \\
$\mathrm{As}$ & $7.93 \pm 0.44$ & $10.12 \pm 1.49$ & 13 & 5.9 & 17 & 33 \\
$\mathrm{~Pb}$ & $21.55 \pm 1.96$ & $23.90 \pm 2.46$ & 20 & 35 & 91.3 & 250 \\
$\mathrm{Co}$ & $3.95 \pm 0.15$ & $4.04 \pm 0.37$ & 19 & NA & NA & NA \\
$\mathrm{Fe}$ & $2317.08 \pm 116.22$ & $2434.67 \pm 165.66$ & 47,200 & NA & NA & NA \\
$\mathrm{Sr}$ & $119.08 \pm 2.91$ & $128.17 \pm 11.59$ & 300 & NA & NA & NA \\
\hline
\end{tabular}

N.B. NA for not available.

During both the pre-and post-monsoon seasons, average heavy metal concentration showed the following sequence: $\mathrm{Fe}>\mathrm{Mn}>\mathrm{Zn}>\mathrm{Cu}>\mathrm{Sr}>\mathrm{Pb}>\mathrm{Cr}>\mathrm{As}>\mathrm{Co}$. However, all the elements showed a higher concentration during the post-monsoon in comparison with the pre-monsoon except for $\mathrm{Zn}$ and $\mathrm{Cu}$. Data showed the highest concentration for the metal Fe. In contrast, the lowest was found for Co. We have compared the heavy metal concentration with the world average shale value [24] and sediment quality guidelines (SQG) [60].

In both pre- and post-monsoon, $\mathrm{Cu}$ showed three (3) times, $\mathrm{Zn}$ showed 1.5 times, and $\mathrm{Pb}$ showed slightly higher concentration than the average shale value. The rest of the heavy metals showed a lower concentration than the average shale values during two seasons (pre-monsoon and post-monsoon). A study conducted in Klang River, Malaysia, found a lower concentration of $\mathrm{Cu}$ than the average shale value, different from this research findings. However, the concentrations of $\mathrm{Zn}$ and $\mathrm{Pb}$ were found to be higher compared to the average shale values, which are similar to the results of these authors, i.e., [61,62].

In North America, numerical sediment quality standards have been used to classify contaminants in aquatic ecosystems for marine and freshwater ecosystems [60]. The threshold effect level (TEL) indicates the concentration below which adverse effects are expected to occur only rarely. Probable effect level (PEL) represents the high concentration of adverse effects, which is expected to occur frequently and severe effect level (SEL), which symbolizes chronic, long-term impacts of contamination to aquatic organisms, particularly benthic organisms. $\mathrm{Cu}, \mathrm{Zn}$, and As showed a higher concentration than TEL but lower than PEL. On the other hand, $\mathrm{Cr}$ and $\mathrm{Pb}$ showed a lower concentration than TEL, indicating that $\mathrm{Cr}$ and $\mathrm{Pb}$ may have adverse effects. There were no sediment quality guidelines for $\mathrm{Co}, \mathrm{Fe}$, and Sr. In the case of Mn, there were no guidelines for TEL and PEL; however, SEL was available, and this study found a lower concentration of Mn than SEL.

However, the variation of trace metal concentration in sediment samples in both seasons, i.e., pre-monsoon and post-monsoon, is not significant $(p>0.05)$. Moreover, metal concentration in the sediment sample is slightly higher in the post-monsoon compared to pre-monsoon. 


\subsection{Sediment Pollution Assessment}

Soil contamination of the Kutubdia Channel was assessed in this study using the indices- contamination factor $(\mathrm{CF})$ and subsequent degree of contamination, modified degree of contamination (MCD) and finally, pollution load index (PLI). All the results are summarized in Table 4. As per the classification by [23], the overall contamination of sediments, based on Cf values, indicated that sediments of Kutubdia Channel were considerably contaminated with $\mathrm{Cu}$ (average $\mathrm{C}_{\mathrm{f}}=3.13$ ), moderately contaminated with $\mathrm{Zn}$ and $\mathrm{Pb}$ (average $\mathrm{C}_{\mathrm{f}}=1.57$ and 1.14, respectively), but indicated signs of low contamination with $\mathrm{Fe}, \mathrm{Cr}, \mathrm{Co}, \mathrm{Sr}, \mathrm{Mn}$, and $\mathrm{As}\left(\mathrm{C}_{\mathrm{f}}<1\right)$. The degree of contamination (CD) is the sum of all the contamination factors during a season. In terms of $C D$, sediment samples of pre-monsoon indicated a low degree of contamination $\left(C_{d}<8\right)$, but post-monsoon showed a moderate degree of contamination $\left(C_{d}>8\right)$. However, the average $C_{d}$ was found 8.01, which, although only slightly greater than 8 , indicated that sediments of the study site had a moderate degree of contamination overall. On the other hand, the modified degree of contamination (MCD) suggested that nil to very low contamination existed in the studied area $\left({ }^{m} C_{d}=0.89\right)$ following the classification by [25].

Table 4. The seasonal variation of $C_{d},{ }^{m} C_{d}$, and PLI based on elemental concentration in sediment, Kutubdia Channel.

\begin{tabular}{|c|c|c|c|c|c|c|c|c|c|c|c|c|c|}
\hline \multirow[t]{2}{*}{ Stations } & \multicolumn{9}{|c|}{ Contamination Factor, Cf } & \multirow[t]{2}{*}{$C_{d}$} & \multirow[t]{2}{*}{${ }^{\mathrm{m}} \mathrm{C}_{\mathrm{d}}$} & \multirow[t]{2}{*}{ PLI } & \multirow[t]{2}{*}{$\begin{array}{c}\text { Contamination } \\
\text { Level }\end{array}$} \\
\hline & $\mathrm{Cr}$ & Mn & $\mathrm{Cu}$ & Zn & As & $\mathrm{Pb}$ & Co & $\mathrm{Fe}$ & Sr & & & & \\
\hline Pre Monsoon & 0.12 & 0.67 & $3.24^{a}$ & 1.58 & 0.61 & 1.08 & 0.21 & 0.05 & 0.4 & 7.94 & 0.88 & 0 & \\
\hline Post Monsoon & 0.14 & 0.71 & $3.01^{\mathrm{a}}$ & 1.55 & 0.78 & 1.2 & 0.21 & 0.05 & 0.43 & 8.07 & 0.9 & 0 & 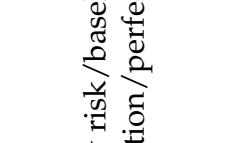 \\
\hline Average & 0.13 & 0.69 & $3.13^{\mathrm{a}}$ & 1.57 & 0.7 & 1.14 & 0.21 & 0.05 & 0.42 & 8.01 & 0.89 & 0 & 占音 \\
\hline
\end{tabular}

Bold values indicate moderate risk, ${ }^{\text {a }}$ Considerable contamination.

The pollution load index (PLI) is another method used to assess heavy metal contamination in sediments. PLI represents the ratio of the metal content in the sediment to the background concentration and indicates the summative level of heavy metal pollution in a particular site [28]. The values of PLI obtained in this study were zero during both seasons. Following the classification by [26], the pollution level based on PLI values indicated baseline deterioration. However, the PLI method does not indicate whether the pollution is anthropogenic or geological in origin.

The index of geo-accumulation indicates the level of pollution by comparing studied elemental concentrations with the respective pre-industrial values. Mean geo-accumulation index for each metal and individual values during pre- and post-monsoon are presented in Table 5.

Table 5. Geo-accumulation index (Igeo) and Enrichment factor (EF) value for heavy metals concentration in soil from Kutubdia Channel, Bangladesh.

\begin{tabular}{|c|c|c|c|c|c|c|c|c|c|c|}
\hline & \multicolumn{9}{|c|}{ Element } & \multirow{2}{*}{$\begin{array}{l}\text { Pollution } \\
\text { Degree }\end{array}$} \\
\hline & Season & $\mathrm{Cu}$ & $\mathrm{Zn}$ & $\mathrm{Pb}$ & Co & As & Mn & $\mathrm{Sr}$ & $\mathrm{Cr}$ & \\
\hline \multirow{3}{*}{$\begin{array}{l}\text { Geo-accumulation } \\
\text { index, } I_{\text {geo }}\end{array}$} & Pre M & 1.11 & 0.07 & -0.48 & -2.85 & -1.3 & -1.16 & -1.92 & -3.66 & \multirow{3}{*}{ Unpolluted } \\
\hline & Post M & 1 & 0.04 & -0.33 & -2.82 & -0.95 & -1.07 & -1.81 & -3.47 & \\
\hline & Average & 1.06 & 0.06 & -0.41 & -2.84 & -1.13 & -1.12 & -1.87 & -3.57 & \\
\hline \multirow{3}{*}{$\begin{array}{l}\text { Enrichment factor, } \\
\text { EF }\end{array}$} & Pre M & $65.9^{b}$ & 32.1 & 21.9 & $4.23^{\mathrm{a}}$ & 12.4 & 13.7 & $8.09^{a}$ & $2.42^{\mathrm{a}}$ & \multirow{3}{*}{$\begin{array}{c}\text { Severe } \\
\text { enrichment }\end{array}$} \\
\hline & Post M & $58.3^{b}$ & 30 & 23.2 & $4.12^{\mathrm{a}}$ & 15.1 & 13.8 & $8.28^{a}$ & $2.63^{a}$ & \\
\hline & Average & $62.1^{b}$ & 31.05 & 22.6 & $4.18^{\mathrm{a}}$ & 13.8 & 13.8 & $8.19^{a}$ & $2.53^{\mathrm{a}}$ & \\
\hline
\end{tabular}

Bold values indicate "Moderately polluted" category; Pre M for pre-monsoon, Post M for post-monsoon. ${ }^{a}$ Minor to moderately severe enrichment, ${ }^{\mathrm{b}}$ Extremely severe enrichment. 
$I_{g e o}$ values for all the elements were slightly higher during pre-monsoon than postmonsoon. Based on Müller's (1969) [27] classification, the present study's data revealed uncontaminated to moderate contamination of sediments by $\mathrm{Zn}$ and moderate contamination by $\mathrm{Cu}$ [27]. The negative $\mathrm{I}_{\text {geo }}$ values for $\mathrm{Pb}, \mathrm{Co}, \mathrm{As}, \mathrm{Mn}, \mathrm{Sr}$, and $\mathrm{Cr}$ revealed that the mean level of these elements in the sediment of the study site is lower than their respective natural background values and thus, indicates no contamination present. Geoaccumulation index for Fe was not shown here because, as mentioned earlier, Fe was used in this study to compute EF due to its prominent natural abundance in soil and hence no contamination concern. Overall, the sediments of the Kutubdia Channel can be regarded as unpolluted since no substantial contamination was found in terms of the analyzed heavy metals.

Enrichment factor (EF) means the extent to which metals are enriched or reduced compared to a particular origin and can be used to distinguish between elements contributed by human intervention from those of geological origin $[63,64]$. The average EF values of the selected heavy metals and respective values during pre-and post-monsoon are shown in Table 5. During both seasons, the average EF values of $\mathrm{As}, \mathrm{Pb}$, and $\mathrm{Mn}$ revealed that the sediments were severely enriched with these metals ( $\mathrm{EF}$ in the order: $\mathrm{Pb}>\mathrm{As}>\mathrm{Mn}$ ), while $\mathrm{Zn}(\mathrm{EF}>30)$ was observed to be very severely enriched in the site. The highest EF value for $\mathrm{Cu}$ ( $\mathrm{EF}>50$ in post-monsoon, $\mathrm{EF}>60$ in pre-monsoon) graded the soil extremely severely enriched with $\mathrm{Cu}$. Among the rest of the metals, $\mathrm{Sr}(\mathrm{EF}>8)$ revealed moderately severe enrichment, $\mathrm{Co}(\mathrm{EF}>4)$ was moderately enriched, and $\mathrm{Cr}(\mathrm{EF}>2)$ showed minor enrichment in the sediment. Overall, the mean $\mathrm{EF}$ values of $\mathrm{Zn}$ and $\mathrm{Cu}$ graded the soils as very severely to extremely severely enriched in both seasons, while the rest of the metals were more or less graded as minor to moderate enrichment. Moreover, in the current study, the average extent of pollution and pre-monsoon and post-monsoon were categorized as severe enrichment.

\subsection{Potential Ecological Risk (PER) Assessment}

The potential ecological risk (PER) is a widely used index for assessing the impact of heavy metals on a particular site's ecology and evaluating the degree of potential ecological risks that indicate the pollution status. The heavy metal contamination of sediments poses direct threats for filter-feeding species, and the subsequent discharge of metals into the water body poses other ecological threats. Thus, the assessment of PER can serve as a tool for understanding and controlling pollution. The results of evaluation on the potential ecological risk factor $\left(\mathrm{E}_{\mathrm{r}}^{\mathrm{i}}\right.$ ) and the potential ecological risk index (RI) from the studied data are summarized in Table 6.

Table 6. Ecological risk factor and PER for heavy metal contaminated sediment sample.

\begin{tabular}{|c|c|c|c|c|c|c|c|c|c|}
\hline \multirow[t]{2}{*}{ Stations } & \multicolumn{7}{|c|}{ Potential Ecological Risk Factors $\left(E_{r}^{i}\right)$} & \multirow{2}{*}{$\begin{array}{c}\text { Risk } \\
\text { Index } \\
\text { (RI) }\end{array}$} & \multirow[t]{2}{*}{$\begin{array}{c}\text { Pollution } \\
\text { Degree }\end{array}$} \\
\hline & $\mathrm{Cr}$ & Mn & $\mathrm{Cu}$ & $\mathrm{Zn}$ & As & $\mathrm{Pb}$ & Co & & \\
\hline Pre Monsoon & 0.06 & 0.67 & 0.65 & 1.58 & 0.06 & 0.22 & 0.04 & 3.27 & Low risk \\
\hline Post Monsoon & 0.07 & 0.71 & 0.6 & 1.55 & 0.08 & 0.24 & 0.04 & 3.29 & Low risk \\
\hline Average & 0.07 & 0.69 & 0.63 & 1.57 & 0.07 & 0.23 & 0.04 & 3.28 & Low risk \\
\hline
\end{tabular}

The $\mathrm{E}_{\mathrm{r}}^{\mathrm{i}}$ values of the studied heavy metal in sediments of Kutubdia Channel were found in the order of $\mathrm{Zn}>\mathrm{Mn}>\mathrm{Cu}>\mathrm{Pb}>\mathrm{As}>\mathrm{Cr}>\mathrm{Co}$ (Table 6). The $\mathrm{E}_{\mathrm{r}}^{\mathrm{i}}$ value of each metal varied only slightly during the two seasons, with values for $\mathrm{Cr}, \mathrm{Mn}, \mathrm{As}$, and $\mathrm{Pb}$ comparatively higher during post-monsoon and that for $\mathrm{Cu}$ and $\mathrm{Zn}$ comparatively higher during pre-monsoon. $E_{\mathrm{r}}^{\mathrm{i}}$ remained the same during both seasons. This seasonal variation of $\mathrm{E}_{\mathrm{r}}^{\mathrm{i}}$ might owe to the differing influx and subsequent deposition of individual heavy metals, resulting in their respective differing abundance in the sediments during the two seasons. 
However, the potential ecological risk factors ( $\left.E_{r}^{i}\right)$ of the studied metals were all lower than 40, which indicated low ecological risk as per classification by [23].

On the other hand, the comprehensive potential ecological risk index (RI) is the sum of all $E_{r}^{\mathrm{i}}$ values which represents the overall potential ecological risk (PER) for a given aquatic ecosystem. It was found that all the sampling sites were at a low-risk level since the RI values were much lower than 150. Overall, the results indicated a low PER for the aquatic system of the Kutubdia Channel based on the studied heavy metals.

\subsection{Human Health Risk Assessment}

The hazard index (HI) and hazard quotients (HQ) values of elemental contamination in soil for children, adult males, and adult females are shown in Table 7.

Table 7. Human health risk estimation for heavy metals contamination in soil collected from Kutubdia Channel, southern region, Bangladesh.

\begin{tabular}{|c|c|c|c|c|c|c|c|c|c|c|}
\hline \multirow{3}{*}{ Metal } & \multicolumn{9}{|c|}{ Hazard Quotients (HQ.) } & \multirow{3}{*}{ Risk Leve } \\
\hline & \multicolumn{3}{|c|}{ Children } & \multicolumn{3}{|c|}{ Adult Male } & \multicolumn{3}{|c|}{ Adult Female } & \\
\hline & ING & INH & DER & ING & INH & DER & ING & INH & DER & \\
\hline $\mathrm{Mn}$ & $5.37 \times 10^{-2}$ & $5.37 \times 10^{2}$ & $4.18 \times 10^{2}$ & $4.23 \times 10^{-3}$ & $4.23 \times 10$ & $3.29 \times 10^{-1}$ & $4.96 \times 10^{-3}$ & $4.96 \times 10$ & $3.86 \times 10^{-1}$ & No risk \\
\hline $\mathrm{Fe}$ & $4.34 \times 10^{-2}$ & 0 & 0 & $3.42 \times 10^{-3}$ & 0 & 0 & $4.01 \times 10^{-3}$ & 0 & 0 & No risk \\
\hline $\mathrm{Cu}$ & $4.49 \times 10^{-2}$ & $4.47 \times 10^{-2}$ & $1.5 \times 10^{-1}$ & $3.54 \times 10^{-3}$ & $3.52 \times 10^{-3}$ & $1.18 \times 10^{-2}$ & $4.15 \times 10^{-3}$ & $4.13 \times 10^{-3}$ & $1.38 \times 10^{-2}$ & No risk \\
\hline $\mathrm{Zn}$ & $6.32 \times 10^{-3}$ & $6.32 \times 10^{-3}$ & $3.16 \times 10^{-2}$ & $4.98 \times 10^{-4}$ & $4.98 \times 10^{-4}$ & $2.49 \times 10^{-3}$ & $5.84 \times 10^{-4}$ & $5.84 \times 10^{-4}$ & $2.92 \times 10^{-3}$ & No risk \\
\hline $\mathrm{Sr}$ & $2.63 \times 10^{-6}$ & 0 & 0 & $2.08 \times 10^{-7}$ & 0 & 0 & $2.43 \times 10^{-7}$ & 0 & 0 & No risk \\
\hline $\mathrm{Pb}$ & $8.3 \times 10^{-2}$ & $8.25 \times 10^{-2}$ & $5.53 \times 10^{-1}$ & $6.54 \times 10^{-3}$ & $6.5 \times 10^{-3}$ & $4.36 \times 10^{-2}$ & $7.67 \times 10^{-3}$ & $7.62 \times 10^{-3}$ & $5.11 \times 10^{-2}$ & No risk \\
\hline As & $3.85 \times 10^{-1}$ & $7.69 \times 10$ & $9.38 \times 10^{-1}$ & $3.03 \times 10^{-2}$ & $6.06 \times 10^{-1}$ & $7.39 \times 10^{-2}$ & $3.55 \times 10^{-2}$ & $7.11 \times 10^{-1}$ & $8.66 \times 10^{-2}$ & No risk \\
\hline $\mathrm{Cr}$ & $4.88 \times 10^{-2}$ & $5.12 \times 10$ & $2.44 \times 10$ & $3.85 \times 10^{-3}$ & $4.03 \times 10^{-1}$ & $1.92 \times 10^{-1}$ & $4.51 \times 10^{-3}$ & $4.73 \times 10^{-1}$ & $2.25 \times 10^{-1}$ & No risk \\
\hline $\mathrm{Co}$ & NA & NA & NA & NA & NA & NA & NA & NA & NA & No risk \\
\hline $\mathrm{HI}$ & $6.65 \times 10^{-1}$ & $5.5 \times 10^{2}$ & $8.29 \times 10$ & $5.24 \times 10^{-2}$ & $4.34 \times 10$ & $6.53 \times 10^{-1}$ & $6.14 \times 10^{-2}$ & $5.08 \times 10$ & $7.66 \times 10^{-1}$ & No risk \\
\hline
\end{tabular}

In three different pathways, direct exposure of humans to heavy metals in contaminated soil can occur. The paths are (a) ingestion, (b) inhalation, and (c) dermal. In the case of children, all the values of $\mathrm{HQ}$ and $\mathrm{HI}$ were generally less than 1 for all the elements except for $\mathrm{Mn}, \mathrm{As}$, and $\mathrm{Cr}$. Both $\mathrm{Mn}$ and $\mathrm{Cr}$ showed $\mathrm{HQ}>1$ in inhalation and dermal pathways, whereas As showed HQ $>1$ for inhalation. The HI indicated health risk for children as $\mathrm{HI}$ values for inhalation and dermal routes were greater than 1 . Similarly to our result, another study found arsenic to be associated with children's health risks through inhalation [9]. Children are more susceptible to soil with metals because of their outdoor play practices; they can consume more heavy metals than adults [65]. Except for Mn, the result showed an HQ value of less than 1 in all three pathways for adult males' elements. However, the HI value for inhalation is greater than 1, indicating potential health risk for adult males through inhalation. A similar pattern has been found in the case of adult females. Except for Mn, all the metals showed $\mathrm{HQ}<1$ in all three pathways for all the heavy metals. Similar to adult males, Mn showed potential health risks through inhalation $(\mathrm{HQ}>1)$. The results showed that $\mathrm{Mn}$ is responsible for health risks for both adult males and females through inhalation exposure. Likewise, this study and another study in China have found a higher $\mathrm{HI}$ value $(\mathrm{HI}>1)$ for inhalation exposure which was considered as a noncarcinogenic risk to adults and children [66].

\subsection{Statistical Analysis}

Cluster analysis (CA) and principal component analysis (PCA) were adopted as statistical methods to identify the sources of elements in sediment and water of the Kutubdia Channel and understand the contribution of natural and/or anthropogenic factors to the origin of the studied elements $[67,68]$.

Cluster analysis was performed to identify the group where the contamination source is the same for the same group elements, as shown in Figure 3. 


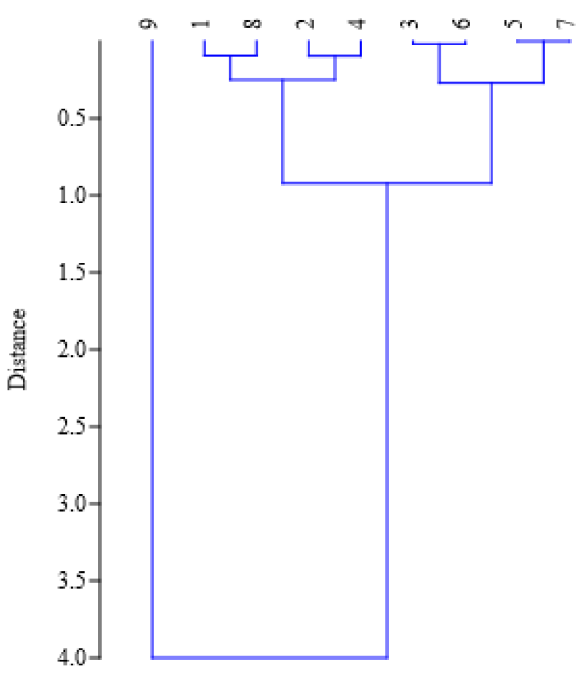

(A)

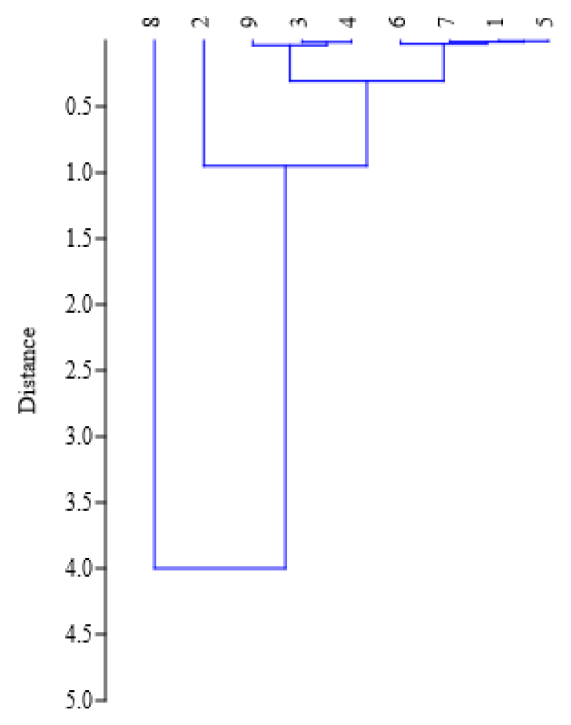

(B)

Figure 3. Cluster analysis in water (A) Dendrogram plot for water and sediment (B) Dendrogram plot for sediment.

This study used a normalized data set to produce dendrograms and followed Ward's method and Euclidean distance for cluster analysis. For the cluster analysis, we used numerical digits for elements like 1, 2, 3, 4, 5, 6,7, 8, and 9 for $\mathrm{Cr}, \mathrm{Mn}, \mathrm{Cu}, \mathrm{Zn}, \mathrm{As}, \mathrm{Pb}, \mathrm{Co}$, $\mathrm{Fe}$, and $\mathrm{Sr}$. However, two clusters are found in the case of nine elemental concentration in a water sample, they are cluster $1(\mathrm{Cr}, \mathrm{Mn}, \mathrm{Zn}$, and $\mathrm{Fe})$ and cluster $2(\mathrm{Cu}, \mathrm{As}, \mathrm{Pb}$, and $\mathrm{Co}$ ). It indicates that four elements of cluster 1 come from the same source and are similar to cluster 2. However, Sr might be from a different source and showed maximum contamination among the nine elements. Moreover, cluster 2 demonstrated a slightly higher concentration compared to cluster 1 . In terms of sediment sample, we found two clusters; one is comprised of $\mathrm{Cr}, \mathrm{As}, \mathrm{Pb}$, and $\mathrm{Co}$ and the other is comprised of $\mathrm{Cu}, \mathrm{Zn}$, and $\mathrm{Sr}$. The contamination level of the two clusters is extremely low. However, both clusters are correlated with $\mathrm{Mn}$ and Fe, where we found comparatively high contamination.

In terms of the water sample, PCA was also performed using the normalized data to identify the factors loadings influencing each one. The loadings of PC1 and PC2 are expressed in Table 8 .

Table 8. Principal component analysis for elemental concentration in water.

\begin{tabular}{ccccc}
\hline Elements & \multicolumn{2}{c}{ PC 1 } & \multicolumn{2}{c}{ PC 2 } \\
\hline & Water & Sediment & Water & Sediment \\
\hline 1. $\mathrm{Cr}$ & -0.29 & -0.68 & 0.04 & 0.002 \\
2. $\mathrm{Mn}$ & -0.02 & 0.38 & 0.10 & 0.01 \\
3. $\mathrm{Cu}$ & -0.61 & -0.44 & -0.01 & -0.014 \\
4. $\mathrm{Zn}$ & -0.10 & -0.43 & -0.01 & -0.01 \\
5. As & -0.89 & -0.68 & -0.02 & 0.003 \\
6. Pb & -0.63 & -0.66 & 0.01 & 0.003 \\
7. Co & -0.89 & -0.69 & -0.02 & 0.002 \\
8. Fe & -0.23 & 3.66 & -0.07 & -0.001 \\
9. Sr & 3.67 & -0.47 & -0.01 & 0.004 \\
Eigenvalue & 2.00 & 2.00 & 0.002 & $4.5 \times 10^{-5}$ \\
\% Variance & 99.88 & 99.998 & 0.12 & 0.002 \\
\hline
\end{tabular}


The percentage of total variance for PC1 is 99.88 , whereas PC2 is 0.12 ; thus, PC1 explained the strong loading of elements, i.e., $\mathrm{Cu}, \mathrm{As}, \mathrm{Pb}, \mathrm{Co}$, and $\mathrm{Sr}(>0.5)$.

In terms of sediment samples, the loadings of PC1 and PC2 were expressed in Table 8. The percentage of total variance for PC1 is 99.998 , whereas PC2 is 0.002; thus, PC1 explained the strong loading of elements, i.e., $\mathrm{Cr}, \mathrm{As}, \mathrm{Pb}, \mathrm{Co}$, and $\mathrm{Fe}(>0.5)$.

\section{Conclusions}

The present investigation reveals that the water of Kutubdia Channel is safe nearly all year round for drinking, fishing, and industrial activities in terms of its $\mathrm{pH}$ and $\mathrm{DO}$. However, the Kutubdia Channel is directly connected with the Bay of Bengal by the north, so salinity (and hence TDS and EC) tends to be higher than the drinking water standards. In terms of elemental contamination of water, the level of all studied metals was below the standard safe level for drinking water established by WHO, U.S. EPA, and DPHE. In this regard, we conclude that the surface water of Kutubdia Channel does not pose any risk of heavy metal contamination if used for irrigation, fishing and thus for human consumption. On the other hand, average heavy metal concentrations in the sediment samples are lower than the TEL for $\mathrm{Cr}$ and $\mathrm{Pb}$, whereas $\mathrm{Cu}, \mathrm{Zn}$, and As show concentrations lower than PEL (but > TEL), and Mn show a lower concentration than SEL. Sediment pollution assessment reveals that sediments of Kutubdia Channel were considerably contaminated with $\mathrm{Cu}$ and moderately contaminated with $\mathrm{Zn}$ and $\mathrm{Pb}$ based on $\mathrm{C}_{\mathrm{f}}$ values. $\mathrm{CD}$ is 'moderate' during post-monsoon, while it is 'low' during pre-monsoon. However, in terms of MCD, nil to very low contamination exists in the studied area. Results also reveal low PER for the aquatic ecosystem of Kutubdia Channel posed by the studied heavy metals. However, human health risk assessment analysis shows that Kutubdia Channel sediments pose some noncarcinogenic risk for children and adults through inhalation; continuous monitoring is suggested.

Author Contributions: Conceptualization, M.S.H. (Md. Solaiman Hossain) and M.K.A.; methodology, Y.N.J., M.J.K., S.A. and M.S.R.; software, M.S.H. (Md. Solaiman Hossain); validation, M.S.H. (Md. Solaiman Hossain); formal analysis, M.S.H. (Md. Solaiman Hossain); investigation, M.K.A. and M.S.R.; resources, M.S.H. (Md. Solaiman Hossain); data curation, Y.N.J., M.J.K., S.A. and M.S.R.; writing—original draft preparation, M.S.H. (Md. Solaiman Hossain), E.L. and M.S.H. (Md. Shahadat Hossain); writing — review and editing, M.S.H. (Md. Solaiman Hossain); visualization, M.S.R.; supervision, M.S.R. and M.K.A.; funding acquisition, M.S.H. (Md. Solaiman Hossain). All authors have read and agreed to the published version of the manuscript.

Funding: We would also thank the Ministry of Science and Technology (Grant number: NST fellowship-39.012.002.01.03.021.2014-135), The People's Republic of Bangladesh for funding.

Data Availability Statement: Not applicable.

Acknowledgments: We want to thank the Atomic Energy Center, Dhaka, for giving a laboratory facility for sample analysis.

Conflicts of Interest: The authors declare no conflict of interest.

\section{References}

1. Jayaprakash, M.; Urban, B.; Velmurugan, P.M.; Srinivasalu, S. Accumulation of total trace metals due to rapid urbanization in microtidal zone of Pallikaranai marsh, South of Chennai, India. Environ. Monit. Assess. 2010, 170, 609-629. [CrossRef] [PubMed]

2. Briffa, J.; Sinagra, E.; Blundell, R. Heavy metal pollution in the environment and their toxicological effects on humans. Heliyon 2020, 6, e04691. [CrossRef] [PubMed]

3. Tchounwou, P.B.; Yedjou, C.G.; Patlolla, A.K.; Sutton, D.J. Heavy metal toxicity and the environment. Exp. Suppl. 2012, 101, 133-164. [CrossRef] [PubMed]

4. Ali, H.; Khan, E.; Ilahi, I. Environmental Chemistry and Ecotoxicology of Hazardous Heavy Metals: Environmental Persistence, Toxicity, and Bioaccumulation. J. Chem. 2019, 2019, 6730305. [CrossRef]

5. Giri, S.; Singh, A.K. Human health risk and ecological risk assessment of metals in fishes, shrimps and sediment from a tropical river. Int. J. Environ. Sci. Technol. 2015, 12, 2349-2362. [CrossRef] 
6. Rahman, M.S.; Saha, N.; Molla, A.H. Potential ecological risk assessment of heavy metal contamination in sediment and water body around Dhaka export processing zone, Bangladesh. Environ. Earth Sci. 2014, 71, 2293-2308. [CrossRef]

7. Ahmad, W.; Alharthy, R.D.; Zubair, M.; Ahmed, M.; Hameed, A.; Rafique, S. Toxic and heavy metals contamination assessment in soil and water to evaluate human health risk. Sci. Rep. 2021, 11, 17006. [CrossRef]

8. Palansooriya, K.N.; Shaheen, S.M.; Chen, S.S.; Tsang, D.C.W.; Hashimoto, Y.; Hou, D.; Bolan, N.S.; Rinklebe, J.; Ok, Y.S. Soil amendments for immobilization of potentially toxic elements in contaminated soils: A critical review. Environ. Int. 2020, 134, 105046. [CrossRef]

9. Rinklebe, J.; Antoniadis, V.; Shaheen, S.M.; Rosche, O.; Altermann, M. Health risk assessment of potentially toxic elements in soils along the Central Elbe River, Germany. Environ. Int. 2019, 126, 76-88. [CrossRef]

10. Hosono, T.; Su, C.-C.; Delinom, R.; Umezawa, Y.; Toyota, T.; Kaneko, S.; Taniguchi, M. Decline in heavy metal contamination in marine sediments in Jakarta Bay, Indonesia due to increasing environmental regulations. Estuar. Coast. Shelf Sci. 2011, 92, 297-306. [CrossRef]

11. Safiur Rahman, M.; Solaiman Hossain, M.; Ahmed, M.K.; Akther, S.; Jolly, Y.N.; Akhter, S.; Jamiul Kabir, M.; Choudhury, T.R. Assessment of heavy metals contamination in selected tropical marine fish species in Bangladesh and their impact on human health. Environ. Nanotechnol. Monit. Manag. 2019, 11, 100210. [CrossRef]

12. Hossain, M.S.; Ahmed, M.K.; Sarker, S.; Rahman, M.S. Seasonal variations of trace metals from water and sediment samples in the northern Bay of Bengal. Ecotoxicol. Environ. Saf. 2020, 193, 110347. [CrossRef]

13. Filgueiras, A.; Lavilla, I.; Bendicho, C. Evaluation of distribution, mobility and binding behaviour of heavy metals in surficial sediments of Louro River (Galicia, Spain) using chemometric analysis: A case study. Sci. Total Environ. 2004, 330, 115-129. [CrossRef]

14. Joksimovic, D.; Tomic, I.; Stankovic, A.R.; Jovic, M.; Stankovic, S. Trace metal concentrations in Mediterranean blue mussel and surface sediments and evaluation of the mussels quality and possible risks of high human consumption. Food Chem. 2011, 127, 632-637. [CrossRef] [PubMed]

15. Luoma, S.N.; Bryan, G. A statistical assessment of the form of trace metals in oxidized estuarine sediments employing chemical extractants. Sci. Total Environ. 1981, 17, 165-196. [CrossRef]

16. Rahman, M.S.; Saha, N.; Molla, A.H.; Al-Reza, S.M. Assessment of Anthropogenic Influence on Heavy Metals Contamination in the Aquatic Ecosystem Components: Water, Sediment, and Fish. Soil Sediment Contam. Int. J. 2014, 23, 353-373. [CrossRef]

17. CPGCBL. The Current Project of CPGCBL (The Coal Power Generation Company Bangladesh Limited): Matarbari Coal Thermal Power Plant; Ministry of Power: Dhaka, Bangladesh, 2021.

18. Oyedotun, T.D.T. X-ray fluorescence (XRF) in the investigation of the composition of earth materials: A review and an overview. Geol. Ecol. Landsc. 2018, 2, 148-154. [CrossRef]

19. Hossain, M.B.; Habib, S.B.; Hossain, M.S.; Jolly, Y.N.; Kamal, A.H.M.; Idris, M.H.; Rakib, M.R.J. Data set on trace metals in surface sediment and water from a sub-tropical estuarine system, Bay of Bengal, Bangladesh. Data Brief 2020, 31, 105911. [CrossRef]

20. Tiwari, M.; Sahu, S.K.; Rathod, T.D.; Bhangare, R.C.; Ajmal, P.Y.; Vinod Kumar, A. Determination of trace elements in salt and seawater samples by energy dispersive X-ray fluorescence spectrometry. J. Radioanal. Nucl. Chem. 2020, 325, 751-756. [CrossRef]

21. Tung, J.W. Determination of metal components in marine sediments using energy-dispersive X-ray fluorescence (ED-XRF) spectrometry. Ann. Chim. 2004, 94, 837-846. [CrossRef] [PubMed]

22. Turner, A.; Taylor, A. On site determination of trace metals in estuarine sediments by field-portable-XRF. Talanta 2018, 190, 498-506. [CrossRef]

23. Hakanson, L. An ecological risk index for aquatic pollution control. A sedimentological approach. Water Res. 1980, 14, 975-1001. [CrossRef]

24. Turekian, K.K.; Wedepohl, K.H. Distribution of the elements in some major units of the earth's crust. Geol. Soc. Am. Bull. 1961, 72, 175-192. [CrossRef]

25. Abrahim, G.M.S.; Parker, R.J. Assessment of heavy metal enrichment factors and the degree of contamination in marine sediments from Tamaki Estuary, Auckland, New Zealand. Environ. Monit. Assess. 2008, 136, 227-238. [CrossRef] [PubMed]

26. Tomlinson, D.; Wilson, J.; Harris, C.; Jeffrey, D. Problems in the assessment of heavy-metal levels in estuaries and the formation of a pollution index. Helgoländer Meeresunters 1980, 33, 566. [CrossRef]

27. Muller, G. Index of geoaccumulation in sediments of the Rhine River. Geojournal 1969, 2, 108-118.

28. Rabee, A.M.; Al-Fatlawy, Y.F.; Nameer, M. Using Pollution Load Index (PLI) and geoaccumulation index (I-Geo) for the assessment of heavy metals pollution in Tigris river sediment in Baghdad Region. Al-Nahrain J. Sci. 2011, 14, 108-114.

29. Abolfazl, N.; Ahmad, I. Risk assessment of mercury contamination in surface sediment of the Klang River, Malaysia. Aust. J. Basic Appl. Sci. 2011, 5, 215-221.

30. Qiao, Y.; Yang, Y.; Zhao, J.; Tao, R.; Xu, R. Influence of urbanization and industrialization on metal enrichment of sediment cores from Shantou Bay, South China. Environ. Pollut. 2013, 182, 28-36. [CrossRef]

31. Zhang, L.; Ye, X.; Feng, H.; Jing, Y.; Ouyang, T.; Yu, X.; Liang, R.; Gao, C.; Chen, W. Heavy metal contamination in western Xiamen Bay sediments and its vicinity, China. Mar. Pollut. Bull. 2007, 54, 974-982. [CrossRef]

32. Neto, J.B.; Smith, B.; McAllister, J. Heavy metal concentrations in surface sediments in a nearshore environment, Jurujuba Sound, Southeast Brazil. Environ. Pollut. 2000, 109, 1-9. [CrossRef] 
33. Zoller, W.H.; Gladney, E.S.; Duce, R.A. Atmospheric concentrations and sources of trace metals at the South pole. Science 1974, 183, 198-200. [CrossRef]

34. USEPA. Human Health Risk Assessment; Environmetal Protection Agency, Ed.; USEPA: Washington, DC, USA, 2020.

35. Ihedioha, J.; Ukoha, P.; Ekere, N. Ecological and human health risk assessment of heavy metal contamination in soil of a municipal solid waste dump in Uyo, Nigeria. Environ. Geochem. Health 2017, 39, 497-515. [CrossRef] [PubMed]

36. Sun, Z.; Chen, J. Risk assessment of potentially toxic elements (PTEs) pollution at a rural industrial wasteland in an abandoned metallurgy factory in North China. Int. J. Environ. Res. Public Health 2018, 15, 85. [CrossRef] [PubMed]

37. Onyele, O.G.; Anyanwu, E.D. Human health risk assessment of some heavy metals in a Rural Spring, Southeastern Nigeria. Afr. J. Environ. Nat. Sci. Res 2018, 1, 15-23.

38. Sojka, M.; Siepak, M.; Zioła, A.; Frankowski, M.; Murat-Błażejewska, S.; Siepak, J. Application of multivariate statistical techniques to evaluation of water quality in the Mała Wełna River (Western Poland). Environ. Monit. Assess. 2008, 147, 159-170. [CrossRef]

39. Siepak, M.; Sojka, M. Application of multivariate statistical approach to identify trace elements sources in surface waters: A case study of Kowalskie and Stare Miasto reservoirs, Poland. Environ. Monit. Assess. 2017, 189, 364. [CrossRef]

40. Sojka, M.; Siepak, M.; Jaskuła, J.; Wicher-Dysarz, J. Heavy Metal Transport in a River-Reservoir System: A Case Study from Central Poland. Pol. J. Environ. Stud. 2018, 27, 1725-1734. [CrossRef]

41. Patil, P.; Sawant, D.; Deshmukh, R. Physico-chemical parameters for testing of water-A review. Int. J. Environ. Sci. 2012, 3, 1194-1207.

42. DPHE. Water Quality Parameters Bangladesh Standards \& WHO Guide Lines; Rahman, M.S., Ed.; DPHE: Dhaka, Bangladesh, 2019.

43. Patel, H.; Vashi, R.T. (Eds.) Chapter 2-Characterization of Textile Wastewater. In Characterization and Treatment of Textile Wastewater; Elsevier: Boston, MA, USA, 2015; pp. 21-71. [CrossRef]

44. Ahmed, M.F.; Rahman, M. Water Supply and Sanitation: Rural and low income urban communities. ITN-Bangladesh; Center for Water Supply and Waste Management, BUET: Dhaka, Bangladesh, 2000; pp. 191-195.

45. Aoi, W.; Marunaka, Y. Importance of $\mathrm{pH}$ homeostasis in metabolic health and diseases: Crucial role of membrane proton transport. BioMed Res. Int. 2014, 2014, 598986. [CrossRef]

46. Khan, M.; Chowdhury, S. Physical and chemical limnology of lake Kaptai, Bangladesh. Trop. Ecol. 1994, $35,35-51$.

47. WHO. Guidelines for drinking-water quality, [Chapter 12] Chemical fact sheets. Fluoride 2011, 38, 370-373.

48. Omer, N.H. Water quality parameters. In Water Quality-Science, Assessments and Policy; Book Chapter; IntechOpen: London, UK, 2019 ; p. 18.

49. Kumar, N.; Kumar, D.; Kumar, S.; Shukla, V.; Shukla, P.; Raj, B. Spatio-temporal variations in hydro-geochemistry of groundwater at rural, urban and industrial areas of Kanpur, India. Environ. Sustain. 2018, 1, 197-208. [CrossRef]

50. Mondal, N.; Singh, V.; Singh, V.; Saxena, V. Determining the interaction between groundwater and saline water through groundwater major ions chemistry. J. Hydrol. 2010, 388, 100-111. [CrossRef]

51. Lawson, E. Physico-chemical parameters and heavy metal contents of water from the Mangrove Swamps of Lagos Lagoon, Lagos, Nigeria. Adv. Biol. Res. 2011, 5, 8-21.

52. Lotliker, A.A.; Baliarsingh, S.K.; Sahu, K.C.; Kumar, T.S. Long-term chlorophyll-a dynamics in tropical coastal waters of the western Bay of Bengal. Environ. Sci. Pollut. Res. 2020, 27, 6411-6419. [CrossRef]

53. Murty, V.; Subrahmanyam, B.; Gangadhara Rao, L.; Reddy, G. Seasonal variation of sea surface temperature in the Bay of Bengal during 1992 as derived from NOAA-AVHRR SST data. Int. J. Remote Sens. 1998, 19, 2361-2372. [CrossRef]

54. EWG. EWG's Guide to Safe Drinking Water: Reduce Your Exposures to Common Drinking Water Pollutants with EWG's Handy Tipsheet; Environmental Working Group (EWG): Washington, DC, USA, 2019; p. 20009.

55. Melnyk, L.J.; Donohue, M.J.; Pham, M.; Donohue, J. Absorption of strontium by foods prepared in drinking water. J. Trace Elem. Med. Biol. 2019, 53, 22-26. [CrossRef]

56. Nordstrom, D.K. Public health. Worldwide occurrences of arsenic in ground water. Science 2002, 296, 2143-2145. [CrossRef]

57. Linos, A.; Petralias, A.; Christophi, C.A.; Christoforidou, E.; Kouroutou, P.; Stoltidis, M.; Veloudaki, A.; Tzala, E.; Makris, K.C.; Karagas, M.R. Oral ingestion of hexavalent chromium through drinking water and cancer mortality in an industrial area of Greece-an ecological study. Environ Health 2011, 10, 5057Liu. [CrossRef]

58. Ward, M.H.; Jones, R.R.; Brender, J.D.; de Kok, T.M.; Weyer, P.J.; Nolan, B.T.; Villanueva, C.M.; van Breda, S.G. Drinking Water Nitrate and Human Health: An Updated Review. Int. J. Environ. Res. Public Health 2018, 15, 1557. [CrossRef]

59. Asante, K.A.; Agusa, T.; Subramanian, A.; Ansa-Asare, O.D.; Biney, C.A.; Tanabe, S. Contamination status of arsenic and other trace elements in drinking water and residents from Tarkwa, a historic mining township in Ghana. Chemosphere 2007, 66, 1513-1522. [CrossRef] [PubMed]

60. MacDonald, D.D.; Ingersoll, C.G.; Berger, T.A. Development and evaluation of consensus-based sediment quality guidelines for freshwater ecosystems. Arch. Environ. Contam. Toxicol. 2000, 39, 20-31. [CrossRef] [PubMed]

61. Woszczyk, M.; Spychalski, W.; Boluspaeva, L. Trace metal (Cd, Cu, Pb, Zn) fractionation in urban-industrial soils of UstKamenogorsk (Oskemen), Kazakhstan-implications for the assessment of environmental quality. Environ. Monit. Assess. 2018, 190, 362. [CrossRef] [PubMed]

62. Lu, J.; Lu, H.; Lei, K.; Wang, W.; Guan, Y. Trace metal element pollution of soil and water resources caused by small-scale metallic ore mining activities: A case study from a sphalerite mine in North China. Environ. Sci. Pollut. Res. Int. 2019, 26, 24630-24644. [CrossRef] [PubMed] 
63. Reimann, C.; de Caritat, P. Distinguishing between natural and anthropogenic sources for elements in the environment: Regional geochemical surveys versus enrichment factors. Sci. Total Environ. 2005, 337, 91-107. [CrossRef] [PubMed]

64. Shotyk, W.; Krachler, M.; Aeschbach-Hertig, W.; Hillier, S.; Zheng, J.J. Trace elements in recent groundwater of an artesian flow system and comparison with snow: Enrichments, depletions, and chemical evolution of the water. J. Environ. Monit. 2010, 12, 208-217. [CrossRef]

65. Wuana, R.A.; Okieimen, F.E. Heavy Metals in Contaminated Soils: A Review of Sources, Chemistry, Risks and Best Available Strategies for Remediation. ISRN Ecol. 2011, 2011, 402647. [CrossRef]

66. Hou, S.; Zheng, N.; Tang, L.; Ji, X.; Li, Y.; Hua, X. Pollution characteristics, sources, and health risk assessment of human exposure to $\mathrm{Cu}, \mathrm{Zn}, \mathrm{Cd}$ and $\mathrm{Pb}$ pollution in urban street dust across China between 2009 and 2018. Environ. Int. 2019, 128, $430-437$. [CrossRef] [PubMed]

67. Said, I.; Salman, S.A.; Elnazer, A.A. Multivariate statistics and contamination factor to identify trace elements pollution in soil around Gerga City, Egypt. Bull. Natl. Res. Cent. 2019, 43, 1-6. [CrossRef]

68. Devi, N.L.; Yadav, I.C.; Shihua, Q.; Dan, Y.; Zhang, G.; Raha, P. Environmental carcinogenic polycyclic aromatic hydrocarbons in soil from Himalayas, India: Implications for spatial distribution, sources apportionment and risk assessment. Chemosphere 2016, 144, 493-502. [CrossRef] [PubMed] 